\title{
The Redeployment of Chechnya-Based Troops to Dagestan: Background, Motives, and Repercussions
}

\author{
Emil Souleimanov and Maya Ehrmann *
}

\section{Introduction}

Chechnya and Dagestan are two key autonomous republics in the North Caucasus. These two republics have the largest populations among the autonomous republics in the region, and have a strong tradition of (political) Islam and extensive experience with religion-driven insurgency flavored by separatist overtones that has been underway in the area since the beginning of the previous decade. Occupying a strategic location on the southernmost frontier of the Russian Federation and bordering Georgia and Azerbaijan, two independent nations of the post-Soviet South Caucasus, the developments in these neighboring autonomous republics have been regarded as crucial for the prospects of the Islamist insurgency in the North Caucasus. Should the self-proclaimed Caucasus Emirate, the leading group of the Islamist insurgency in the region, establish a firm presence in Chechnya and Dagestan, the chances of the federal authorities to successfully address the ongoing political violence in its southern provinces would decrease dramatically. This would pave the way for a considerable deterioration of the security situation in the whole of the North Caucasus, with possible repercussions in Russia's other regions with significant Muslim populations.

In mid-March 2012, a massive redeployment of military personnel from Chechnya to Dagestan took place. According to unofficial sources from Dagestan, between 2025,000 troops from Chechnya (primarily troops belonging to the Ministry of Interior) were moved to the neighboring republic. ${ }^{1}$ A military column including large numbers of armored fighting vehicles set out from Khankala, a military base east of Grozny, to the Karabudakhkent district of Dagestan on the outskirts of the capital city of Makhachkala. ${ }^{2}$ Vyacheslav Makhmudov, a spokesman for Dagestan's regional Interior Ministry, claimed that "[w]e are talking about a temporary deployment and coordination to pre-

* Emil Souleimanov is an assistant professor of Russian and East European Studies at Charles University in Prague, Czech Republic. Maya Ehrmann is a student of security studies at the Inter-Disciplinary Center (IDC) in Herzliya, Israel. This article was written within the framework of the Research Intent of the Faculty of Social Sciences, Charles University in Prague.

1 Valery Dzutsev, "Dagestan's President Promises a Decisive Crackdown on the Insurgency," Eurasia Daily Monitor 9:70 (9 April 2012); available at http://www.jamestown.org/single/? no_cache $=1 \&$ tx_ttnews[tt_news] $=39241$.

2 " $2 \overline{5}, 000$ Troops and More than 300 Armored Vehicles Deployed in Dagestan," Kavkascenter.com (17 March 2012); available at http://kavkazcenter.com/eng/content/2012/03/17/ 15983 print.html. 
vent and counter terrorism and extremism across the whole territory of Dagestan." 3 Dagestani President Magomedsalam Magomedov further stated that this addition of troops would "enable us to maintain law and order and fight extremism and terrorism more effectively." 4 Rationalized by the authorities as another means of improving the deteriorating situation in the Caspian republic, this move has caused serious concern both within and outside of Dagestan. The number of troops recently redeployed to Dagestan is staggeringly high, leading to concern over whether Russia's intentions in this area may go beyond a mere attempt to stabilize Dagestan. ${ }^{5}$ There is further concern over the ethnic composition of the troops. ${ }^{6}$

Broadly speaking, this article is an attempt to reveal the potential of ChechenDagestani conflict, the likelihood of which has increased recently due to the redeployment of Chechen (and Chechnya-based) troops from Chechnya to Dagestan. In particular, we seek to discern the significance of the redeployment of these troops to Dagestan. We shall initially provide some background for Chechen-Dagestani tensions in the region, the growth of the Islamist insurgency in Dagestan, and the instigation and expansion of "Kadyrovization" in the scope of the fight against the insurgency. We shall then introduce some possible rationales behind Moscow's troop redeployment to Dagestan as well as address some of the likely implications, both locally and regionally. Our aim shall be achieved by analyzing the motivations and repercussions of this decision.

\section{Background}

\section{Chechen-Dagestani Tensions: A Brief History}

Apart from the traditional sense of rivalry and competitiveness, the peoples of the Caucasus, Chechens and Dagestanis - who are close to each other in both their shared culture and their history of fierce anti-colonial resistance dating back to the end of the eighteenth century - have faced incidents of conflict in the near past. The story began in 1944, when the Chechens, accused by the NKVD (Stalin's internal security agency) of collaboration with Nazi Germany, were deported en masse to Central Asia, and the politico-administrative map of the autonomous republic of Chechen-Ingushetia was redrawn, with some of its eastern territories permanently rendered to Dagestan. In the second half of the following decade, the Chechens were allowed to return to their native lands and

3 Stepan Kravchenko and Ilya Arkhipov, "Russia Deploying Troops for Temporary Dagestan Reinforcement," Bloomberg.com (19 March 2012); available at http://www.bloomberg.com/ news/2012-03-19/russia-deploying-troops-for-temporary-dagestan-reinforcement-1-.html.

4 "Police Presence in Dagestan to be Reinforced to Counter Terrorism," Interfax News Agency (23 March 2012), 1.

5 J. E. Dyer, "Russian Troop Deployments in the South," HotAir.com (24 March 2012); available at http://hotair.com/greenroom/archives/2012/03/24/russian-troop-deployments-in-thesouth.

6 Valery Dzutsev, "Russia Launches Massive Military Redeployment to Dagestan," Eurasia Daily Monitor 9:57 (21 March 2012); available at http://www.jamestown.org/single/?no cache $=1 \&$ tx_ttnews[tt_news] $=39160$. 
homes, but found them taken by Dagestanis, particularly newcomers from the ranks of Laks and Avers. ${ }^{7}$ This experience on the part of the Chechens of being supplanted laid the foundation for future intractable tensions; in fact, the issue of the rehabilitation of deportees, including their property rights and politico-administrative control over disputed areas, has not yet been resolved. Accordingly, the Novolakskiy district (known as the Aukhovskiy district until 1944) has until now been claimed by both Laks and Akkiy Chechens, members of one of nine Chechen tukhums native to the area. Although the Chechens' preoccupation with Moscow-related issues in the post-Soviet period seems to have largely diverted their attention away from Dagestan, Chechen nationalists have, from time to time, voiced territorial claims to some neighboring areas. Most notably, in 2006, Dukuvakha Abdurakhmanov, the then-chairman of the pro-Kremlin National Assembly of the Chechen Republic, made an infamous statement indirectly claiming not only the Novolakskiy district for the Chechens, but also Kizlyar and Khasavyurt, the biggest cities of East-Central Dagestan, and access to the Caspian Sea. ${ }^{8}$ This statement outraged many Dagestanis, and caused serious frictions between the two peoples.

\section{Growth of the Insurgency in Dagestan}

Although Dagestan is a predominantly Muslim country made up of some of the first communities in the North Caucasus to embrace Salafism, instances of Islamic insurgency there were extremely uncommon up until a decade ago. ${ }^{9}$ Many factors may help feed the steady growth of the insurgency in Dagestan. Foremost among these, the collapse of the Soviet Union led to instability in Dagestan, and the consequent rise of (political) Islamism. This instability was characterized by high unemployment, corruption, poverty, and other social problems. ${ }^{10}$ The establishment of an Islamist state was perceived by some to be a potential solution to these problems. ${ }^{11}$ Islamism, which the Russian authorities strongly associated with terrorism and considered a primary threat to Russia's security, had been approached with suspicion before 2000. Russian authorities employed harsh, and sometimes corrupt, tactics of interrogation against suspected

7 International Crisis Group, "Russia's Dagestan: Conflict Causes," Europe Report No. 192 (3 June 2008); available at http://www.crisisgroup.org/ /media/Files/europe/192_russia_s_ dagestan_conflict_causes.pdf.

8 "US Embassy Cables: A Wedding Feast, the Caucasus Way," The Guardian (U.K.) (1 December 2010; publication of cable originally sent 31 August 2006); available at http://www.guardian.co.uk/world/us-embassy-cables-documents/76763.

9 Emil Souleimanov, "The Republic of Dagestan: The Epicenter of Islamist Insurgency in Russia's North Caucasus," IPRIS Occasional Paper 4 (Portuguese Institute of International Relations and Security, December 2011); available at http://www.ipris.org/?menu=6\&page=56.

10 Edward C. Holland and John O'Loughlin, "Ethnic Competition, Radical Islam, and Challenges to Stability in the Republic of Dagestan," Communist \& Post-Communist Studies 43:3 (2010): 297-308.

11 Moshe Gammer, "From the Challenge of Nationalism to the Challenge of Islam: The Case of Daghestan," in Ethno-Nationalism, Islam and the State in the Caucasus: Post-Soviet Disorder, ed. Moshe Gammer (Abingdon: Routledge, 2007), 179-93. 
Dagestanis, and arrested many real or alleged 'Wahhabis.' This included their subjection to torture and other forms of violence. In line with the local tradition of male honor, such treatment motivated some of those who had been 'wronged' and their relatives to turn to violence as a means of redeeming the honor of their family or clan. The support of Islamist insurgents has given individuals tools for retaliatory attacks against authorities and a platform for protest against corruption, social and economic problems, and the deterioration of traditional values. The increasing influence of the insurgent movement in Dagestan has served to mitigate differences rooted in ethnic and clan-based loyalties and establish a greater sense of solidarity. ${ }^{12}$ This sense of solidarity, combined with the experience of corruption, social and economic problems, and the growing influence of Chechen insurgents - who, due to the stringent anti-insurgency tactics of Ramzan Kadyrov, have turned to Dagestan as a base for their operations - have been crucial factors in the growth of the insurgency in Dagestan.

\section{“Kadyrovization" and Chechen Incursions into Dagestan}

With the regional increase of the insurgency campaign, and Dagestan having become a sort of safe haven for Chechen insurgents, Ramzan Kadyrov's influence may spread to Dagestan in the name of counterinsurgency. Following the end of the first Chechen War in 2000, and with the rise of Islamic insurgency and instability in this region, Russian President Vladimir Putin introduced policies allocating "responsibility for ensuring security in the republic to the Chechen people." 13 A key component of these policies was the transfer of administration of Chechnya (and the fight against insurgency) to the Kadyrov clan, a policy often dubbed "Kadyrovization." ${ }^{14}$ Indeed, Ahead Kadyrov (who was assassinated in 2004), and later his son Ramzan Kadyrov (the current head of the Chechen Republic), have adopted a grueling and heavy-handed approach toward fighting the insurgents, while simultaneously cementing a monopoly on power for the Kadyrov clan. ${ }^{15}$ Kadyrov's utilization of aggressive counterinsurgency tactics has undermined Dagestani authorities, and has sometimes breached territorial boundaries for the purpose of counterinsurgency operations. ${ }^{16}$ Without consulting Dagestani authorities, Chechen kadyrovtsy units in the first half of the previous decade undertook a series of incursions into Dagestani territory (regions that happened to also be claimed by the Chechens) to

12 Emil Souleimanov, "Dagestan: The Emerging Core of the North Caucasus Insurgency," $C A C I$ Analyst (29 September 2010); available at http://www.cacianalyst.org/?q=node/5415.

13 Paul Goble, "Russia: Analysis from Washington - Chechenization," Radio Free Europe/Radio Liberty (8 June 2000); available at www.rferl.org/articleprintview/1094108.html.

14 Zaindi Choltaev, "The Failure of 'Chechenization,"” North Caucasus Analysis 5:31 (3 August 2004); available at http://www.jamestown.org/programs/nca/single/?tx_ttnews\%5Btt_news \%5D=1999\&tx_ttnews\%5BbackPid\%5D=186\&no_cache=1.

15 Mikhail Roshchin, "Caucasus Emirate: Virtual Myth or Reality?," North Caucasus Analysis 10:10 (13 March 2009); available at http://www.jamestown.org/single/?no_cache=1\&tx_ ttnews\%5Btt_news\%5D=34708.

16 Emil Pain, "The Kadyrov-ication of Dagestan," North Cacausus Analysis 6:19 (18 May 2005); available at www.jamestown.org/single/?no_cache=1\&tx_ttnews\%5Btt_news\%5D=2900. 
carry out "anti-terrorist operations." In 2009, Dagestan's State Council released a statement claiming that: " $\ldots$ armed people have crossed the administrative border between the Chechen Republic and Dagestan in vehicles with no registration plates without submitting to the legitimate requirements of Dagestan Interior Ministry officers carrying out their duties at road check points and implementing the inspection and registration of road transport." 17

These incursions caused tensions between Grozny and Makhachkala, and drove a wedge between Chechen and Dagestani law enforcement agencies, consequently renewing Dagestanis' established mistrust toward the real objectives of the Chechens. After all, the very failure of the joint Chechen-Dagestani Salami army in August 1999which had been led by Chechen commanders who invaded western Dagestan from Chechnya with the goal of orchestrating a widespread rebellion against Russia and creating an Islamic Republic ${ }^{18}$ - is often explained by the popular defiance of Dagestanis against what they regarded as a masked effort made by Chechens to realize their longstanding territorial claims to Dagestani soil. As a result, what the Salamis hoped would spark a massive anti-Russian rebellion in the neighboring country and pave the ground for establishing a Muslim theocracy in the Caucasus, turned out to be the beginning of the end of the de facto independent Chechen state.

\section{Motives}

Although not much information about the nature of the troops or their redeployment plans has been made available by Russian authorities, according to some sources the troops of the newly established unit will most likely be deployed in the critical districts of Sergokala, Kizlyar, and Izberbash, along with some in the Karabudakhkent district. In institutional terms, the redeployment of Chechnya-based troops to Dagestan has been carried out within the framework of the Temporary Operational Group of the Ministry of Interior that has recently been formed. ${ }^{19}$ While the proportion of ethnically Chechen troops in the redeployed units remains disputed, it seems that Chechens constitute a near-majority of the troops. ${ }^{20}$

The recent move to make use of Chechnya-based troops in fighting the Dagestani insurgency is part of a larger effort by Moscow to strengthen the Dagestan-based military that dates back to the final years of the previous decade, when the scope of the insur-

17 “Dagestan not Happy about Ramzan's Visit," North Caucasus Analysis 6:3 (18 January 2005); available at http://www.jamestown.org/programs/nca/single/?tx_ttnews\%5Btt_news\%5D=21 28\&tx_ttnews\%5BbackPid\%5D=187\&no_cache=1.

18 Pénélope Larzillière, "Chechnya: Moving toward Islamic Nationalism?," in The Enigma of Islamic Violence, ed. Amelie Blom, Laetitia Bucaille, and Luis Martinez (London: Hurst, 2007), 89-104.

20 Dzutsev, "Russia Launches Massive Military Redeployment to Dagestan." 
gency in the republic had become alarming. ${ }^{21}$ In fact, several reasons may underlie Moscow's move. First, the unprecedented intensification of diversionary activities carried out by Dagestani insurgents since 2010 has made Dagestan the heart of the North Caucasus insurgency. ${ }^{22}$ The parallel liquidation of insurgency leaders has had little effect in breaking down the backbone of Islamist resistance. Dagestan's President Magomedsalam Magomedov stated that: "everybody is fed up with this threat [the insurgency]. We want to get rid of, to clean our land of, all kinds of extremists, terrorists, radicals as soon as possible." ${ }^{23}$ Furthermore, a report by Russia's Prosecutor General's Office states, "The criminogenic situation in the Republic of Dagestan remains tense and is marked by the steady growth of threats coming from militants, supporters, and accomplices of terrorist groups. ${ }^{24}$ In this regard, two violent incidents that took place in the republic in early March - both in the strategically located Karabudakhkent district, with its forested mountains - seem to have triggered Moscow's decision to redeploy troops to Dagestan. On 6 March 2012, a suicide bombing carried out by a female attacker at a police checkpoint claimed the lives of five officers and injured two others. ${ }^{25}$ Three days later, in a bold gesture, Dagestani insurgents shot down a Russian military helicopter close to the village of Gubden, which is considered to be one of the strongholds of the Dagestani insurgency. ${ }^{26}$

Second, after more than a decade of a vicious counterinsurgency campaign led by Ramzan Kadyrov and his associates that has cost lives of many hundreds of Chechens and terrified hundreds of thousands of others, the cost of joining the insurgency or providing support or even sympathy to it has been high for many Chechens, a factor that has reduced the material support available to the Chechnya-based Islamists, causing them to seek a base in Dagestan. Kadyrov has often promoted to both Moscow and his Dagestani colleagues his desire to share his experience in effectively combating an Islamist insurgency. As early as the middle of the last decade, he often made statements explicitly blaming the incompetent Dagestani siloviki for the unstable situation in Chechnya, as Chechen Islamists were given a de facto safe haven in Dagestan. ${ }^{27}$ Needless to say,

21 Cerwyn Moore, "The Roots and Transformation of the Dagestan Insurgency," Eurasia Daily Monitor 7:175 (29 September 2010); available at http://www.jamestown.org/programs/edm/ single/?tx_ttnews\%5Btt_news\%5D=36961\&tx_ttnews\%5BbackPid\%5D=484\&no_cache=1. Emil Souleimanov, "Dagestan: The Emerging Core of the North Caucasus Insurgency."

23

24 "Prosecutor General's Office Points to Shortcomings in Efforts to Prevent Terrorism in Dagestan," Interfax News Agency (29 September 2011), 1; available at http://www.interfax.co.uk/ russia-cis-military-news-bulletins-in-english/prosecutor-generals-office-points-toshortcomings-in-efforts-to-prevent-terrorism-in-dagestan-2/.

25 "Russian Bombing is Latest in Spate of Violence," CNN World (7 March 2012); available at http://articles.cnn.com/2012-03-07/world/world_europe_russia-bombing_1_dagestan-russianbombing-suicide-bomber?_s=PM:EUROPE.

26 "CE Mujahideen Shot Down Russian KGB Helicopter in Dagestan," Kavkazcenter.com (9 March 2012); available at http://kavkazcenter.com/eng/content/2012/03/09/15934.shtml.

27 Robert B. Ware, "Mythology and Political Failure in Chechnya," in Chechnya: From Past to Future, ed. Richard Sakwa (London: Anthem Press, 2005), 79-116. 
Kadyrov's participation in Dagestan-based operations may further increase his self-image as an effective counterinsurgency commander in the region. In turn, this participation could strengthen Kadyrov's standing vis-à-vis Moscow, as he would be quick to capitalize on any benefit to be gained from improvements in economic and political issues in the North Caucasus.

Third, Dagestan borders Azerbaijan, which provides an access route to Iran. With the increase in military cooperation between Azerbaijan, the U.S., and Israel, Russian authorities may anticipate an attack on Iran. ${ }^{28}$ In April of this year, Dimitry Rogozin, the Deputy Prime Minister of Russia, claimed, "If Iran is involved in any military action, it's a direct threat to our security." ${ }^{29}$ This statement implies that the recent troop redeployment to Dagestan may be motivated by more than just a desire to fight the insurgency there, but also by fear of possibly growing instability in the region that could result from an attack on Iran. Thus, the Russian military buildup in Dagestan, and in the region in general, may also reflect an attempt to protect Russia's vital interests and possibly even aid Iran in case of an attack against it.

\section{Implications}

The stationing of Chechen troops on Dagestani soil, with their prospective deployment in combat operations, has the potential to threaten the inter-ethnic balance in Dagestan and further already present (though rather weak) anti-Chechen sentiments among some Dagestanis. In fact, given the strong pattern of ethnic factionalism present in Dagestan, leading politico-administrative, economic, and police positions in the republic's respective districts are often dominated by members of the same ethnic group (usually the demographically strongest in a given region). This composition has somewhat reduced the scope of the conflict, as members of both law enforcement agencies and insurgents located in the same area often belong to the same ethnic group, clan, or family.

However, following the Chechen example, incidents of insurgency-related intra-ethnic violence have become increasingly widespread over recent years, and Dagestani authorities have generally sought to deploy ethnically-mixed police troops so as to make these troops more reliable and combat-ready. Despite being highly controversial, what made the counterinsurgency tactics of the Chechen kadyrovtsy units generally effective in their home country (when compared to the Russian Army) was their familiarity with the domestic social terrain, as they were able to gather intelligence and use various coercive tactics toward the persons (or their family members) engaged in the insurgency or supporting it, while usually leaving unmolested people who had no (alleged) links to the Islamists. This tactic gradually reduced the material support available to the insurgents. Familiarity with the domestic terrain is what the redeployed troops will lack while carrying out operations in Dagestan; instead, their deployment in Dagestan might turn into a series of indiscriminate and ruthless punitive campaigns carried out on alien soil that

28 Dyer, "Russian Troop Deployments in the South."

29 F. Michael Maloof, "Russia is Massing Troops on Iran's Northern Border and Waiting for a Western Attack," Business Insider (9 April 2012); http://www.thetruthseeker.co.uk/?p=46671. 
would certainly outrage Dagestanis, regardless of their ethnic loyalties and political preferences. ${ }^{30}$ Indeed, the Moscow-initiated redeployment of Chechen troops (to which Dagestani authorities were opposed until the very last moment) might further exacerbate the delicate interethnic balance in the country and prompt general resentment toward the Chechens both within and outside the republic. Against this background, the established anxiety between members of Dagestani and Chechen law-enforcement agencies could also play a role. The anxiety of Dagestani silovikis toward the activities of their Chechen colleagues on the former's soil is likely to rise significantly, and may consequently alter the nature of the counterinsurgency campaign in Dagestan, as future counterinsurgency efforts may become less synchronized. Accordingly, Ramzan Kadyrov may possibly seek to play a more significant role in the political life of the neighboring multiethnic republic on the shores of the Caspian Sea and, thereby, turn it into a Chechnya-like sultanistic regime.

\section{Conclusion}

The official reason provided by Russia's Interior Ministry for the redeployment of Chechnya-based troops to Dagestan was to "stabilize the situation in Dagestan." 31 The rising threat of insurgency in Dagestan; the intense counterinsurgency campaign in Chechnya by Ramzan Kadyrov, which pushed insurgents to seek new grounds for operations; and the possible threat of instability due to an attack on Iran via Azerbaijan have been significant factors behind Moscow's decision to redeploy troops to Dagestan. However, the nature of this redeployment - the exact numbers of troops involved and their ethnic makeup - remains unclear. The composition of the redeployed troops (should a large number of them prove to be Chechen) may threaten the delicate interethnic balance in Dagestan, and lead to increased ill will and mistrust between Dagestanis and Chechens, a factor that may subsequently affect the nature of counterinsurgency efforts of Chechens and Dagestanis on Dagestani soil. Besides the mistrust that may ensue between Dagestani and Chechen law enforcement authorities, counterinsurgency efforts may be further weakened in that troops originally based in Chechnya will most likely be unfamiliar with the domestic socio-political terrain of Dagestan and will, therefore, be unable to utilize tribal affiliations and territorial familiarity to their advantage in countering the insurgency.

Finally, the troop redeployment may instigate growth in Kadyrov's regional influence. When considering possible causes for the rise of the insurgency in Dagestan, the increased crackdown on insurgents (Moscow's reasoning for redeploying troops to Dagestan) and upon any people suspected of being Islamists may prove to have the adverse effect of fueling the insurgency rather than starving it. Indeed, the redeployment of Chechnya-based troops to Dagestan is a questionable move when one considers the

\footnotetext{
${ }^{30}$ For precedent, see Valery Dzutsev, "Kremlin Counter-Insurgency Efforts Deepen Animosity in Dagestan," Eurasia Daily Monitor 8:94 (16 May 2011); available at http://www.jamestown.org/single/?no_cache=1\&tx_ttnews\%5Btt_news\%5D=37933.

" Dzutsev, "Russia Launches Massive Military Redeployment to Dagestan."
} 
problems that may arise from the troops' ethnic composition as well as this move's possibility of increasing Kadyrov's influence in the region. Despite official statements by Moscow as to the reasons for this redeployment, the sheer number of troops redeployed, Dagestan's proximity to Azerbaijan, and heightened tensions between Azerbaijan and Iran all lead to the speculation that Moscow's move in Dagestan may have resulted from considerations larger than those of regional stability, and may have repercussions that greatly transcend the borders of this region. 


\section{Bibliography}

Choltaev, Zaindi. "The Failure of 'Chechenization'." North Caucasus Analysis 5, no. 31 (2004).

Dzutsev, Valery. "Dagestan's President Promises a Decisive Crackdown on the Insurgency." Eurasia Daily Monitor 9, no. 70 (2012).

Dzutsev, Valery. "Kremlin Counter-Insurgency Efforts Deepen Animosity in Dagestan." Eurasia Daily Monitor 8, no. 94 (2011).

Dzutsev, Valery. "Russia Launches Massive Military Redeployment to Dagestan." Eurasia Daily Monitor 9, no. 57 (2012).

F. Maloof, Michael. "Russia is Massing Troops on Iran's Northern Border and Waiting for a Western Attack." Business Insider (9 April 2012 (2012).

Gammer, Moshe. "From the Challenge of Nationalism to the Challenge of Islam: The Case of Daghestan." In Ethno-Nationalism, Islam and the State in the Caucasus: PostSoviet Disorder. Abingdon: Routledge, 2007.

Holland, Edward C., and John O’Loughlin. "Ethnic Competition, Radical Islam, and Challenges to Stability in the Republic of Dagestan." Communist \& Post-Communist Studies 43 (2010): 297-308.

Larzillière, Pénélope. "Chechnya: Moving toward Islamic Nationalism?" In The Enigma of Islamic Violence. London: Hurst, 2007.

Moore, Cerwyn. "The Roots and Transformation of the Dagestan Insurgency." Eurasia Daily Monitor 7, no. 175 (2010).

Souleimanov, Emil. "The Republic of Dagestan: The Epicenter of Islamist Insurgency in Russia's North Caucasus." PRIS Occasional Paper 4 (2012). 